\title{
Characterization and Inheritance of Four Induced Leaf Mutants in Common Bean
}

\author{
Mark J. Bassett ${ }^{1}$ \\ Vegetable Crops Department, Institute of Food and Agricultural Sciences, University of Florida, \\ Gainesville, FL 32611
}

Additional index words. Phaseolus vulgaris, marker genes

\begin{abstract}
Dry seeds of common bean (Phaseolus vulgaris L.) were treated with $20 \mathrm{krad}(1 \mathrm{rad}=0.01 \mathrm{~Gy})$ of gamma rays to induce plant mutations to be used as genetic markers in mapping studies. Four leaf mutants are described and illustrated. Inheritance studies demonstrated that each is controlled by a single recessive gene. The proposed gene symbols are: $\mathrm{cml}$ for chlorotic moderately lanceolate leaf, $l b d$ for leaf-bleaching dwarf, $g l b$ for glossy bronzing leaf, and 01 for overlapping leaflets. Linkage tests involving $\mathrm{cml}$ and nine previously reported marker mutants failed to detect any linkages.
\end{abstract}

In Phaseolus vulgaris, 206 genes, including members of allelic series, are recognized by the Genetics Committee of the Bean Improvement Cooperative (Bassett, 1989). Few are suitable marker genes that can be conveniently classified in segregating populations. A program was initiated in 1979 to induce mutations to increase the number of favorable marker genes. This paper presents the results of inheritance studies with four leaf mutations.

\section{Materials and Methods}

In 1982, dry seed of breeding line 182-1 was treated with 20 $\operatorname{krad}(1 \mathrm{rad}=0.01 \mathrm{~Gy})$ of gamma rays from a Gammator Model M, Cs 137 source, at a dose of $\approx 2000 \mathrm{R} /$ rein. The $\mathrm{M}_{1}$ plants were grown in the field, and seed were harvested separately from each plant. In $1983 \mathrm{M}_{2}$ plots were planted using up to 100 seeds/plot. A mutant designated "chlorotic moderately lanceolate" leaf (CML) was discovered in $\mathrm{M}_{2}$ plot 3-479. The degree of chlorosis is moderate, and vegetative vigor is adequate for plants to be competitive in mixed stands with normal plants. Fertility and seed yield are about normal. The mutant was truebreeding in greenhouse-grown $\mathrm{M}_{3}$ progeny and was crossed to 182-1. The $\mathrm{F}_{2}$ was planted in the field in 1985 in plot 5-495 and classified for mutant segregation. The CML mutant was crossed and backcrossed with breeding line 5-593 in 1988 and 1989. The $\mathrm{BC}_{1}-\mathrm{F}_{2}$ and $18 \mathrm{BC}_{1}-\mathrm{F}_{3}$ progeny tests of normal (nonmutant) $\mathrm{BC}_{1}-\mathrm{F}_{2}$ selections (from 24 greenhouse-grown plants, Jan. to Mar. 1990) were planted in the field in Apr. 1990 and were classified for mutant segregation.

In 1984 dry seed of breeding line 182-1 were treated with 20 krad of gamma radiation, and $M_{1}$ and $M_{2}$ seed were produced as described above. The $\mathrm{M}_{2}$ generation was planted in the field in 1985 in separate plots for each $\mathbf{M}_{1}$ parent. Three mutants were discovered in separate $\mathrm{M}_{2}$ plots.

The first was designated "overlapping leaflets" (OL). The margins of the terminal and lateral leaflets overlap. The terminal leaflet is less responsive to sunlight than normal, i.e., the leaflet does not rotate from the pulvinule to orient toward or away from the light in response to light and water stress. Thus, the three

Received for publication 3 May 1991. Accepted for publication 23 Jan. 1992. Fla. Agr. Expt. Sta. Journal Series no. R-01106. This research was supported in part by the U.S. Dept. of Agriculture, Cooperative State Research Service/ Special Research Grants program (Tropical Subtropical Agr.). The cost of publishing this paper was defrayed in part by the payment of page charges. Under postal regulations, this paper therefore must be hereby marked advertisement solely to indicate this fact.

'Professor of Horticulture. leaflets have a tendency to remain in the same plane under conditions that stimulate normal plants to reorient their leaflets.

The second mutant was designated glossy bronzing leaflets (GLB). The leaf lamina has a reduced area compared to nonmutant leaves of 5-593. The leaf surface has a sheen, and the leaf color is usualy a slightly darker green than normal. Under bright sunlight, the leaves have scattered patches showing a slight bronzing reaction. Bronzing does not occur under glass.

The third mutant was designated "leaf-bleaching dwarf" (LBD). This mutant produces a distinctive dwarfing under field conditions and under glass, and the dwarfing affects all plant parts proportionally. The pod walls have greatly reduced fiber content, which is similar to the three spindly branch mutants (Bassett, 1990). The chlorophyll in the leaflets and petioles degrades ("bleaches") in irregular patches both in the field and under glass (although not always under glass), which results in creamy white or pure-white structures.

Each of the three mutants (OL, GLB, and LBD) was truebreeding in $\mathrm{M}_{2}$ progeny tests and was crossed to 5-593. The $\mathrm{F}_{2}$ populations from these three crosses were planted in the field in 1987 and classified for mutant segregation. The backcross to 5-593 was made in 1989 for each of the three mutants, and the $\mathrm{BC}_{2}-\mathrm{F}_{2}$ and $\mathrm{BC}_{2}-\mathrm{F}_{3}$ progeny tests (produced in the same way as for CML above) were planted in the field in 1990. The number of $\mathrm{BC}_{1}-\mathrm{F}_{3}$ plots was 14 for OL, 17 for $\mathrm{LBD}$, and 18 for GLB.

Repulsion phase linkage tests were made between the CML mutant and numerous other marker mutations: $s b-1, y, r f d g s$, rnd, do, sil, dia, and cc (Awuma and Bassett, 1988; Bassett, 1989; Nagata and Bassett, 1984a, 1984b). Crosses were made between $\mathrm{CML}$ and each of the mutants, and $\mathrm{F}_{2}$ populations were

Table 1. Segregation for mutant phenotypes in $\mathrm{F}_{2}$ populations of beans derived from the following mutant $\times$ normal crosses: cross no. 1,3 479 with CML mutant $\times 182-1$; cross no. 2 , 6-223 with LBD mutant $\times 5-593$; cross no. 3 , 6-225 with GLB mutant $\times 5-593$; and cross no. $4,6-231$ with OL mutant $\times 5-593$.

\begin{tabular}{lcccc}
\hline \hline \multirow{2}{*}{$\begin{array}{l}\text { Cross } \\
\text { (no.) }\end{array}$} & \multicolumn{2}{c}{ Phenotypic classes } & $x^{2}$ & $\begin{array}{c}P \\
\text { value }\end{array}$ \\
\cline { 2 - 3 } 1 & Normal & Mutant & $3: 1$ & 0.78 \\
2 & 407 & 132 & 0.08 & 0.52 \\
3 & 264 & 95 & 0.41 & 0.84 \\
4 & 335 & 114 & 0.04 & 0.76 \\
\hline
\end{tabular}

Abbreviations: CML, chlorotic moderately lanceolate; GLB, glossy bronzing; LBD, leaf-bleaching dwarf; OL, overlapping leaflets. 

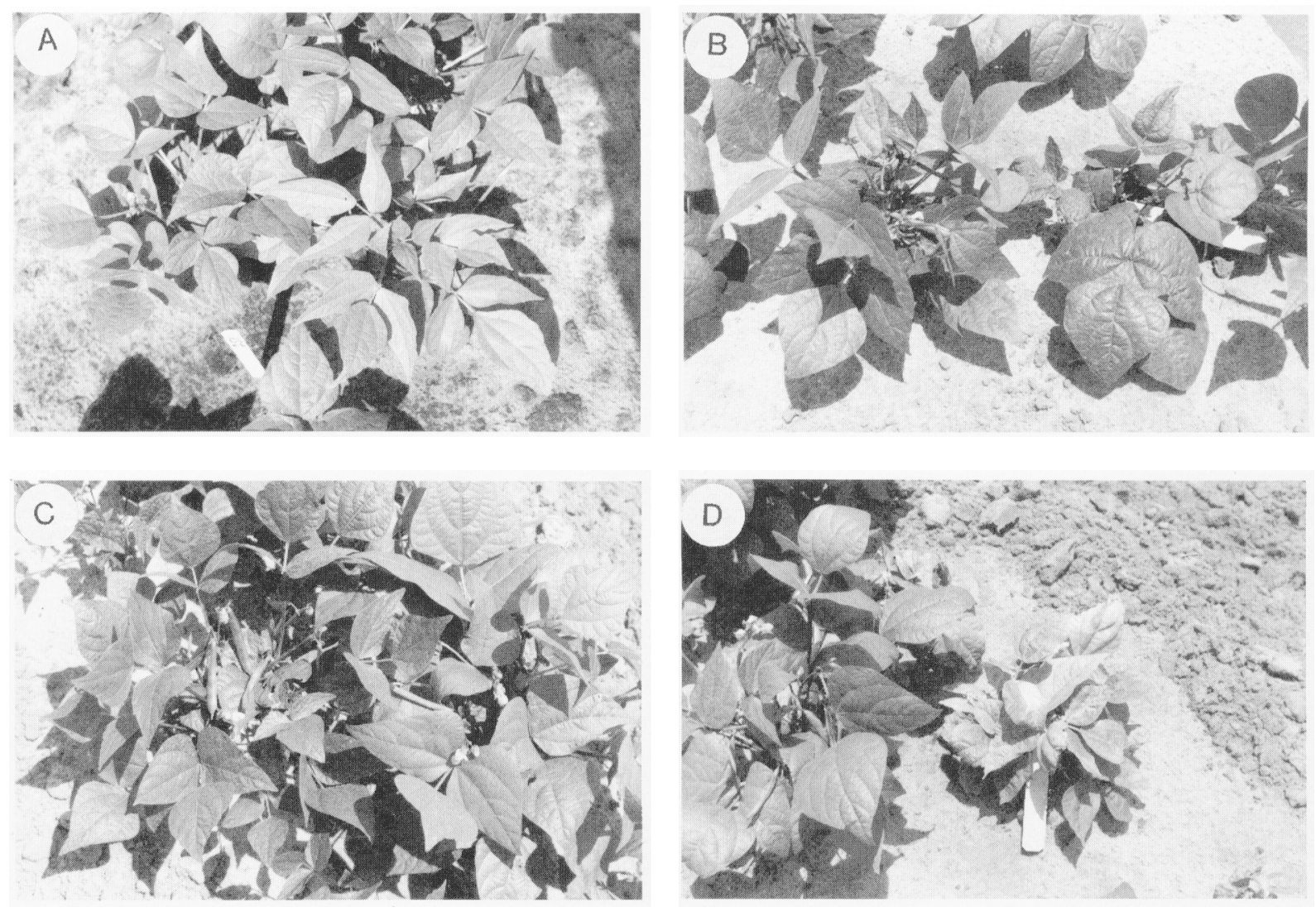

Fig. 1. Photographs of induced mutations. (A) Plant at lower right with moderately lanceolate leaves and slight chlorosis, $\mathrm{cml}$; other plants normal. (B) Plant on' right with overlapping leaflets, ol; normal plant on left. (C) Plant on left with smaller, darker green leaves that are glossy and have scattered patches of light bronzing; normal plant on right. (D) Plant on right with dwarf habit and irregular patches of white or creamy white on its leaves and an overall moderate chlorosis, $l b d$; normal plant on left.

Table 2. Segregation in $\mathrm{BC}-\mathrm{F}_{2}$ populations derived from crosses of bean mutants with breeding line 5-593.

\begin{tabular}{|c|c|c|c|c|}
\hline \multirow{2}{*}{$\begin{array}{l}\text { Mutant } \\
\text { symbol }\end{array}$} & \multicolumn{2}{|c|}{ Phenotypic classes } & \multirow{2}{*}{$\begin{array}{c}x^{2} \\
3: 1\end{array}$} & \multirow{2}{*}{$\begin{array}{c}P \\
\text { value }\end{array}$} \\
\hline & Normal & $\overline{\text { Mutant }}$ & & \\
\hline$\overline{\mathrm{cml}}$ & 103 & 37 & 0.15 & 0.70 \\
\hline$l b d$ & 252 & 73 & 1.18 & 0.29 \\
\hline$g l b$ & 117 & 40 & 0.019 & 0.89 \\
\hline ol & 294 & 100 & 0.031 & 0.86 \\
\hline
\end{tabular}

Table 3. BC-F progeny tests of randomly selected normal BC-F segregants of beans from crosses of induced mutants by 5-593 (recurrent parent).

\begin{tabular}{|c|c|c|c|c|}
\hline \multirow{2}{*}{$\begin{array}{l}\text { Mutant } \\
\text { symbol }\end{array}$} & \multicolumn{2}{|c|}{ Classification of $\mathrm{F}_{3}$ progenies } & \multirow{2}{*}{$\begin{array}{c}x^{2} \\
2: 1\end{array}$} & \multirow{2}{*}{$\underset{\text { value }}{P}$} \\
\hline & Segregating & Nonsegregating & & \\
\hline$\overline{\mathrm{cml}}$ & 11 & 7 & 0.25 & 0.62 \\
\hline$l b d$ & 12 & 5 & 0.118 & 0.73 \\
\hline$g l b$ & 12 & 6 & 0.00 & 1.00 \\
\hline ol & 6 & 8 & 3.57 & 0.06 \\
\hline & \multicolumn{2}{|c|}{ Phenotypic classification $^{2}$} & $x^{2}$ & \\
\hline & Normal & Mutant & $3: 1$ & \\
\hline $\mathrm{cml}$ & 385 & 117 & $\overline{0.768}$ & 0.38 \\
\hline$l b d$ & 462 & $119^{y}$ & 6.325 & 0.012 \\
\hline$g l b$ & 442 & 144 & 0.057 & 0.81 \\
\hline ol & 198 & 74 & 0.706 & 0.40 \\
\hline
\end{tabular}

${ }^{2}$ Data for all segregating progenies were combined for each mutant.

${ }^{y}$ The expected value was 145.25 ; a shortage of 26 plants was observed.
Table 4. Repulsion linkage tests involving $\mathrm{F}_{2}$ populations of beans from cross combinations between $\mathrm{cml}$ and other marker mutations.

\begin{tabular}{|c|c|c|c|c|c|c|}
\hline \multirow{2}{*}{$\begin{array}{l}\text { Marker } \\
\text { tested }\end{array}$} & \multicolumn{4}{|c|}{ Phenotypic classification } & \multirow{2}{*}{$\begin{array}{c}x^{2} \\
9: 3: 3: 1\end{array}$} & \multirow{2}{*}{$\begin{array}{c}P \\
\text { value } \\
\end{array}$} \\
\hline & Normal & $\mathrm{cml}$ & Marker & Double & & \\
\hline$s b-1$ & 309 & 96 & 110 & 24 & 3.94 & 0.27 \\
\hline$y$ & 134 & 45 & 39 & 11 & 1.44 & 0.70 \\
\hline of & 328 & 107 & 106 & 24 & 3.96 & 0.27 \\
\hline dgs & 307 & 89 & 112 & 24 & 5.44 & 0.14 \\
\hline md & 320 & 114 & 108 & 24 & 4.28 & 0.23 \\
\hline do & 326 & 91 & 99 & 25 & 4.97 & 0.17 \\
\hline sil & 215 & 60 & 55 & 13 & 7.48 & 0.06 \\
\hline dia & 303 & 109 & 104 & 21 & 5.50 & 0.14 \\
\hline$c c$ & 328 & 103 & 98 & 29 & 2.07 & 0.56 \\
\hline
\end{tabular}

classified into four phenotypic classes: normal, the two singlemutant classes, and the double-mutant class (double recessive segregants). The data were analyzed for goodness-of-fit to the expected ratio 9:3:3:1.

\section{Results and Discussion}

Crosses between normal breeding lines and each of the four mutants resulted in $\mathrm{F}_{1}$ progeny that were nonmutant (data not shown). The $\mathrm{F}_{2}$ populations of the above crosses segregated in a 3:1 ratio for normal and mutant plants, respectively (Table 1). The results are consistent with the hypothesis that each of the four mutants is controlled by a single recessive gene.

Gene symbols are proposed for the mutants based on these results and other test results presented below. The symbol $\mathrm{cml}$ 
for chlorotic moderately lanceolate leaf is proposed for the CML mutant (Fig 1A). The symbol 01 for overlapping leaflets is proposed for the OL mutant (Fig. 1B). The symbol $g l b$ for glossy bronzing leaflets is proposed for the GLB mutant (Fig. 1C). The symbol $l b d$ for leaf-bleaching dwarf is proposed for the LBD mutant (Fig. 1D).

Each of the mutants was backcrossed to 5-593 to convert them to a common genetic background. The $\mathrm{BC}-\mathrm{F}_{2}$ segregation was once again in good agreement with a 3:1 segregation hypothesis for normal and mutant plants, respectively (Table 2). Segregation in $\mathrm{BC}-\mathrm{F}_{3}$ progenies showed good agreement with the expected 2:1 ratio (segregating to nonsegregating progenies), except for the 01 mutant, which gave a low but acceptable $P$ value of 0.06 (Table 3 ). This deviation appears to be purely random in view of the good fit to a 3:1 segregation (normal to mutant) in the combined $\mathrm{BC}-\mathrm{F}_{3}$ data from segregating $\mathrm{BC}-\mathrm{F}_{2}$ progenies involving the 01 mutant (Table 3 ). The other mutants gave a good fit to a 3:1 ratio (normal to mutant), except for the lbd mutant, which showed a shortage of mutant segregants great enough to produce a significant deviation from expected $(P=$ 0.012 ). The shortage was due to stress caused by an environment $\times$ herbicide interaction that killed $l b d$ seedlings at a higher rate than normal seedlings. Night temperatures near freezing were recorded during seedling emergence and this was exacerbated by an interaction with the herbicide 2-chloro-N-(2-ethyl6-methylphenyl)-N-(2-methoxy-1-methylethyl)acetamide (metolachlor) that produced severe necrosis on the primary leaves.
Considering all the evidence (Tables 2 and 3), the hypothesis that each of the mutants is controlled by a single recessive gene is confirmed.

Linkage tests were made by crossing $\mathrm{cml}$ with nine other marker mutants. Analysis of $\mathrm{F}_{2}$ data showed that none of the populations deviated significantly from the expected segregation ratio of 9:3:3:1 (Table 4). There is no evidence of linkage between any of the markers tested and the $\mathrm{cml}$ locus. Six of the marker genes tested are located in linkage groups VI, VII, and IX (Bassett, 1991), whereas the remaining three are in undetermined linkage groups.

\section{Literature Cited}

Awuma, K. and M.J. Bassett. 1988. Addition of genes for dwarf seed $(d s)$ and spindly branch $(s b)$ to the linkage map of common bean. J. Amer. Soc. Hort. Sci. 113:464-467.

Bassett, M.J. 1989. List of genes-Phaseolus vulgaris L. Annu. Rpt. Bean Improv. Coop. 32:1-15.

Bassett, M.J. 1990. Three mimic mutants for spindly branch in common bean and tests for linkage with other mutants. HortScience 25:1280-1281.

Bassett, M.J. 1991. A revised linkage map of common bean. HortScience 26:834-836.

Nagata, R.T. and M.J. Bassett. 1984a. Characterization and inheritance of gamma ray induced mutations in common bean. J. Amer. Soc. Hort. Sci. 109:513-516.

Nagata, R.T. and M.J. Bassett. 1984b. Linkage relationships of nine induced mutants in common bean. J. Amer. Soc. Hort. Sci. 109:517518 . 